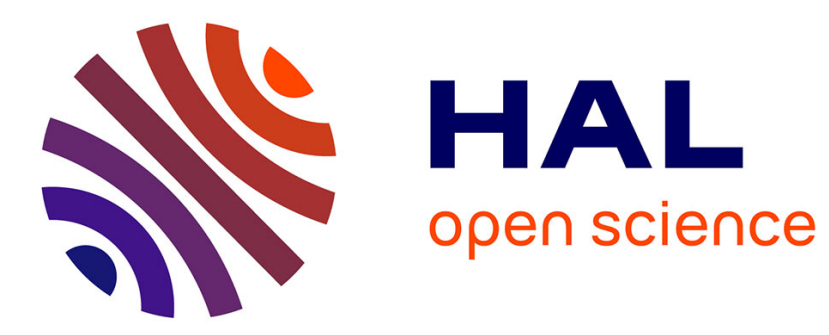

\title{
Cationic motion in dehydrated zeolites
}

R. Schoonheydt

\section{- To cite this version:}

R. Schoonheydt. Cationic motion in dehydrated zeolites. Journal de Physique Colloques, 1980, 41 (C6), pp.C6-261-C6-264. 10.1051/jphyscol:1980666 . jpa-00220104

\section{HAL Id: jpa-00220104 https://hal.science/jpa-00220104}

Submitted on 1 Jan 1980

HAL is a multi-disciplinary open access archive for the deposit and dissemination of scientific research documents, whether they are published or not. The documents may come from teaching and research institutions in France or abroad, or from public or private research centers.
L'archive ouverte pluridisciplinaire $\mathbf{H A L}$, est destinée au dépôt et à la diffusion de documents scientifiques de niveau recherche, publiés ou non, émanant des établissements d'enseignement et de recherche français ou étrangers, des laboratoires publics ou privés. 


\title{
Cationic motion in dehydrated zeolites
}

\author{
R. A. Schoonheydt \\ Centrum voor Oppervlaktescheikunde en Colloidale Scheikunde, K.U. Leuven \\ De Croylaan, 42, 3030 Heverlee, Belgium
}

\begin{abstract}
Résumé. - Les ions échangeables dans les zéolithes $X$ et $Y$ déshydratées, sont localisés sur plusieurs sites, différents entre eux du point de vue coordination et énergie potentielle. Le nombre de sites vides est du même ordre de grandeur que le nombre de sites occupés. Il en suit que la migration des cations est corrélée. La relaxation diélectrique est décrite par un moment dipolaire par cubo-octahèdre. La grandeur de ce moment dépend de la composition cationique des cubo-octahèdres. La conductivité ionique est due au mouvement des cations dans les supercages. Le mouvement corrélé demande un facteur de corrélation de conductivité ionique dans l'équation de Nernst-Einstein à part du facteur de corrélation géométrique.
\end{abstract}

\begin{abstract}
The exchangeable cations in dehydrated zeolites, types $\mathrm{X}$ and $\mathrm{Y}$, are located on several energetically and coordinatively different sites. The number of vacant sites is of the same orde: of magnitude as the number of occupied sites. As a result, the motions of the cations as evidenced by the dielectric relaxation and electrical conductivity, are highly correlated. The dielectric relaxation can be described in terms of a dipole moment per cubooctahedron, the magnitude of which depends on the number of cations in the cubooctahedron. The ionic conduction due to the movement of the cations in the supercages, requires the introduction of an ionic conductivity correlation factor besides the classical geometrical correlation factor in the Nernst-Einstein equation.
\end{abstract}

1. Introduction. - In dehydrated, synthetic zeolites, types $\mathrm{X}$ and $\mathrm{Y}$, the exchangeable cations occupy well-defined sites. These sites are distinguished in two aspects : the coordination offered by the lattice oxygens and their place in the cavities [1].

Table I gives a survey and figure 1 shows a general view of the structure. The number of exchangeable cations depends on the $\mathrm{Si}$ : Al ratio and is typically 86 for X-type and 56 for Y-type zeolites. This is less than the number of available sites. Consequently, specific cationic distribution patterns exist, depending on the properties of the exchangeable cations and the site characteristics [2].

The mobility of the exchangeable cations was measured with the electrical conductivity technique in the frequency range $200-3 \times 10^{6} \mathrm{~Hz}$ and up to $750 \mathrm{~K}$. Ionic relaxations and ionic conduction are revealed and assigned to specific cationic motions. The ionic relaxations around room temperature are

Table I. - Description of exchangeable cation sites for zeolites $X$ and $Y$.

\begin{tabular}{lccl} 
Site & $\begin{array}{c}\text { Number of } \\
\text { coordinating } \\
\text { oxygens }\end{array}$ & $\begin{array}{c}\text { Number of sites } \\
\text { per unit cell }\end{array}$ & \multicolumn{1}{c}{ Cavity } \\
\hline I & - & - & - \\
I' $^{\prime}$ & 6 & 16 & hexagonal prism \\
II' $^{\prime}$ & 3 & 32 & cubooctahedron \\
II & 3 & 32 & cubooctahedron \\
II & 3 & 32 & supercage \\
& 4 & 48 & supercage
\end{tabular}

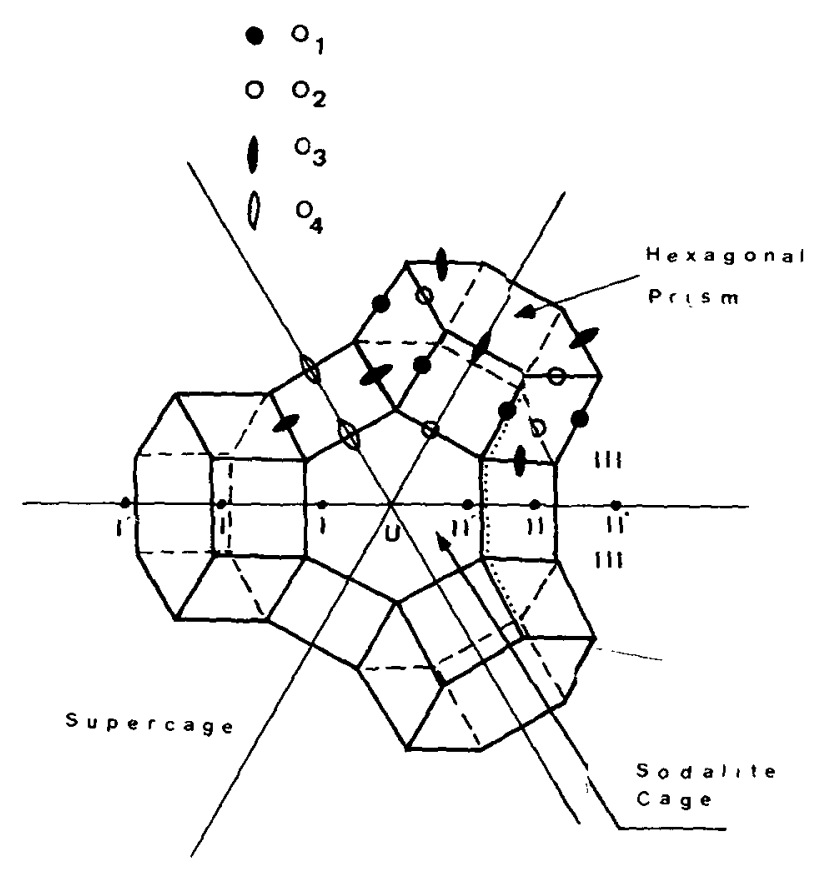

Fig. 1. - Schematic drawing of the structure of zeolites $\mathrm{X}$ and $\mathrm{Y}$.

due to local motion of cations in the vicinity of sites III between two occupied sites II. Ionic relaxations above $\sim 400 \mathrm{~K}$ are ascribed to cationic jumps inside the cubooctahedra, while ionic conduction was due to migration of exchangeable cations in the super- 
cages. The arguments for these assignments are given in the original papers [3-5].

However when it comes to an analysis of these movements in terms of elementary jump processes, the nature of the system imposes a physically important boundary condition : the number of available vacant sites is of the same order of magnitude as the number of diffusing cations. As a consequence, every cationic jump disturbs the equilibrium confguration of exchangeable cations in its surroundings and highly correlated motions result. The situation is similar to that of such superionic conductors as $\beta$-alumina. In the following paragraphs these correlations are taken into account to explain the cationic mobility in these systems.

2. Ionic relaxation. - In one cubooctahedron 4 sites $\mathrm{I}^{\prime}$ and 4 sites $\mathrm{II}^{\prime}$ are available, but in dehydrated zeolites only sites $\mathrm{I}^{\prime}$ are occupied. Correlations between site occupancies are derived from the fact that because of electrostatic repulsions sites $I$ and $I^{\prime}$ on one hand and sites $\mathrm{II}^{\prime}$ and $\mathrm{II}$ on the other hand cannot be occupied simultaneously [6]. The potential energy of cations on the sites $I^{\prime}$ depends on the occupancy of neighbouring sites but also on the $\mathrm{Si}^{4+}$ and $\mathrm{Al}^{3+}$ distributions in the lattice and the coordinating properties of the exchangeable cation under investigation.

On the atomic scale every cation in the cubooctahedron faces an energetically heterogeneous surface. Consequently, the elementary ionic diffusion or local electrical conductivity varies from site to site. The resulting relaxation process will be characterized by a distribution of relaxation times $[7,8]$.

The elementary dipole is formed between the cation on site $\mathrm{I}^{\prime}$ and the negatively charged lattice. The dipole moment length is not the cation-oxygen distance or the jump distance, but the statistical average of the projections of all the possible cationic orientations on the electric field axis [9]. Thus, the experimentally measured dipole moment is not the dipole moment per cation in the cubooctahedron, but the average dipole moment per cubooctahedron. Only with one exchangeable cation per cubooctahedron the two dipole moments are equal. When there is more than one cation in the cubooctahedron, the dipole moment of the cubooctahedron is the vectorial sum of the dipole moments associated with the individual cations. When one cation jumps to a neighbouring site, the other adapts itself to the new situation and the individual dipole moments cannot be resolved.

Clearly, when there are no exchangeable cations in the cuboocta hedron, or when all the sites are occupied, there is no net dipole moment and no ionic relaxation.

To substantiate these ideas the dipole moment per cubooctahedron was estimated from the experimental intensities of the ionic relaxations [3-5] and the cation occupancies $[2,10,11]$ with neglect of the distribution of relaxation times. The Onsager-Kirkwood relation [12] was used :

$$
\varepsilon_{\mathrm{s}}-\varepsilon_{\infty}=\frac{3 \varepsilon_{\mathrm{s}}}{2 \varepsilon_{\mathrm{s}}+\varepsilon_{\infty}}\left(\frac{\varepsilon_{\mathrm{s}}+2}{3}\right)^{2} \frac{\mu_{\mathrm{eff}}^{2} N}{3 \varepsilon_{0} k T} .
$$

The experimental data are summarized in table II together with the calculated dipole moments, $\mu_{\text {eff }}$. When they are plotted as a function of the number of elementary positive charges per cubooctahedron a plot is obtained which satisfies the theoretical deductions (Fig. 2). At zero and full occupancies of site I' the dipole moment per cubooctahedron approaches zero.

Table II. - Dipole monnents per cubooctahedron.

\begin{tabular}{|c|c|c|c|c|c|}
\hline Sample & $\begin{array}{l}\text { Cations per } \\
\text { cubooctahedron }\end{array}$ & $\begin{array}{l}T \\
\mathrm{~K}\end{array}$ & $\varepsilon_{\mathrm{s}}$ & $\varepsilon_{\infty}$ & $\begin{array}{c}\mu_{\text {eff }} \\
\mathrm{cm} \times 10^{29}\end{array}$ \\
\hline - & - & 一 & $\rightarrow$ & 一 & - \\
\hline *NaF5 & 2.37 & 519 & 5.3 & 29.0 & 2.87 \\
\hline NaHF5(1) & 1.40 & 640 & 3.0 & 37.0 & 4.12 \\
\hline NaHF5(2) & 0.50 & 631 & 4.7 & 10.0 & 0.79 \\
\hline CaF5 & 0.325 & 627 & 2.9 & 21.9 & 1.52 \\
\hline CuF5 & 1.40 & 625 & 5.6 & 18.6 & 1.76 \\
\hline $\mathrm{LaF} 2.5$ & 1.00 & 800 & 3.0 & 23.0 & 1.06 \\
\hline
\end{tabular}

* The chemical symbol denotes the exchangeable cation in the cubooctahedron, $F$ the zeolites and the number following this sample symbol is the $\mathrm{SiO}_{2}: \mathrm{Al}_{2} \mathrm{O}_{3}$ ratio.

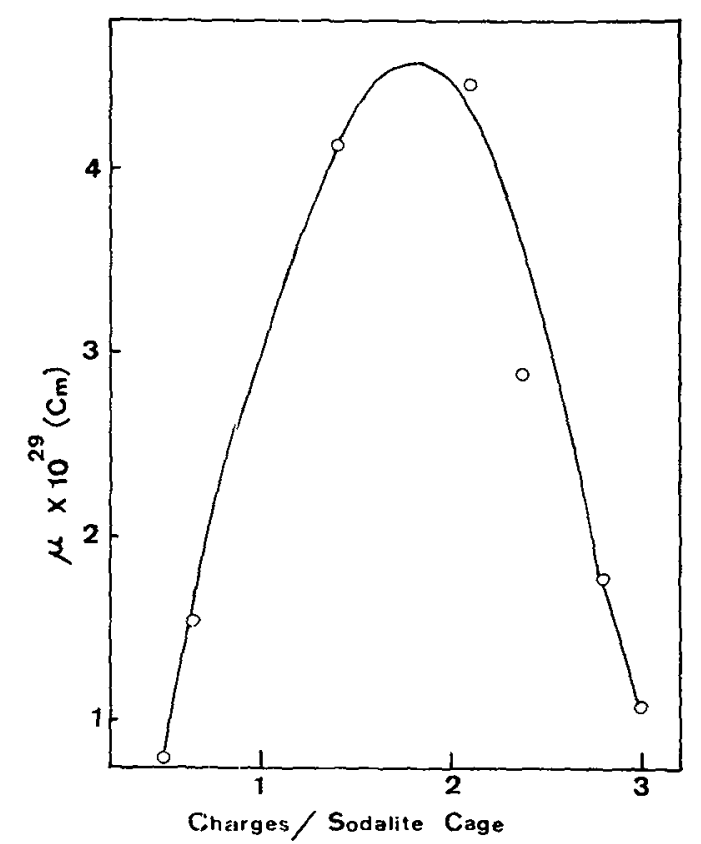

Fig. 2. - The dipole moment per cubooctahedron as a function of the number of cha.rges (in terms of number of monovalent cations) per cubooctahedron.

It is maximum when 2 out of the 4 sites $I^{\prime}$ are occupied by monovalent cations. Divalent and trivalent cations fit the curve of figure 2 when they are taken equivalent to 2 and 3 monovalent cations respectively. Thus, the idea of a dipole moment per cubooctahedron has a physical meaning. 
The following picture emerges when a large temperature domain is investigated. Below $400 \mathrm{~K}$ the cationic jump frequency is too low to obtain a measurable relaxation intensity.

As the temperature raises and thus the jump frequency, the relaxational intensity increases. Above a fixed temperature, characteristic for the zeolite and the type of exchangeable cation, the migration is no longer restricted to the cubooctahedra but jumps between cubooctahedra and supercages become possible. They do not contribute to the relaxation process. A dynamic equilibrium is established between cubooctahedra and supercages. The relaxational intensity is at maximum intensity or decreases slightly. This behavior was experimentally verified $[4,5]$.

In conclusion, it is clear that this picture of a cationic relaxation, restricted inside a cubooctahedron can be generalized to any cation moving between 2 closely spaced boundaries. This is the case, for instance, for $\mathrm{Na}^{+}$on sites III in the supercages, around room temperature [3]. These $\mathrm{Na}^{+}$ions move between 2 sites II occupied by $\mathrm{Na}^{+}$.

As the mobility of $\mathrm{Na}^{+}$on II is low with respect to $\mathrm{Na}^{+}$on III, the occupied sites II constitute at room temperature unsurmountable barriers and $\mathrm{Na}^{+}$on III oscillates around site III, giving rise to an ionic relaxation. The corresponding average dipole moment was calculated to be $3.32 \times 10^{-30} \mathrm{~cm}$.

3. Ionic conduction. - The ionic conduction in dehydrated zeolites $\mathrm{X}$ and $\mathrm{Y}$ is governed by the cations on sites II in the supercages. The elementary jump processes can be envisaged as II $\rightarrow$ III $\rightarrow$ II [3-5]. This system of sites in the supercages constitutes a superlattice structure. Every cationic jump in the superlattice disturbs the equilibrium distribution of the exchangeable cations. It necessitates the introduction in the Nernst-Einstein relation of a supplementary correlation factor $f_{\mathrm{k}}$, besides the structural correlation factor [13-15] :

$$
\frac{\sigma}{D}=\frac{n e^{2}}{k T} \frac{f_{\mathrm{I}}}{f}
$$

The room temperature cation distribution of a homogeneous series of $\mathrm{K}^{+}$-saturated zeolites has
Table III. - Correlation coefficients for ionic conductivity in $\mathrm{K}^{+}$-zeolites.

\begin{tabular}{|c|c|c|c|c|}
\hline & $F_{48.2}$ & $F_{54.7}$ & $F_{69.8}$ & $F_{86.5}$ \\
\hline$p_{0}$ & 0.816 & 0.838 & 0.903 & 0.800 \\
\hline$q_{0}$ & 0.033 & 0.092 & 0.310 & 0.796 \\
\hline$f(300 \mathrm{~K})$ & 0.3668 & 0.4226 & 0.5269 & 0.9215 \\
\hline$f_{1}(300 \mathrm{~K})$ & 0.3913 & 0.4899 & 0.7650 & 1 \\
\hline$W\left(\mathrm{kJmol}^{-1}\right)$ & 9.66 & 7.22 & 4.38 & 1.74 \\
\hline
\end{tabular}

$p_{0}$, occupancy of sites II ; $q_{0}$, occupancy of sites III $W$, the potenthal energy difference of $\mathrm{K}^{+}$on sites II and III; $f_{\mathrm{l}}$, is the ionic conductivity correlation factor and $f$, the geometrical correlation factor. The number after the sample $F$ is the number of $k T$ per unit cell.

been published [6] together with an analysis of the potential energy difference between the exchange sites [16]. This allows a calculation of the correlation factors with the path probability method [13-15]. Table I shows the ionic conductivity correlation factor $f_{\mathrm{I}}$ and the geometrical correlation factor $f$. $F_{1}$ increases monotonically with site occupation $\rho\left[=1 / 2\left(p_{0}+q_{0}\right)\right]$ to reach the value 1 for nearly equal occupancies of the 2 sites i.e. no potential energy difference between sites II and III'. Such a behavior satisfies the theoretical predictions [13-15]. $F$ is composed of the individual correlation coefficients of the 2 migration processes :

$$
f_{\mathrm{II} \rightarrow \mathrm{III}} \text { and } f_{\mathrm{III} \rightarrow \mathrm{II}}: \frac{1}{f}=\frac{1}{2}\left(\frac{1}{f_{\mathrm{II} \rightarrow \mathrm{III}}}+\frac{1}{f_{\mathrm{III}} \rightarrow \mathrm{II}}\right) \text {. }
$$

Its value depends on the diffusion mechanism. In the limit of $\rho \rightarrow 1$ this mechanism is an interstitialcy mechanism for which $f \rightarrow 1$ (17) as shown by our results. It should be interesting to investigate the behavior of the correlation factors for isostructural zeolites with $\rho<0.4$ but they do not exist.

Acknowledgment. - The author acknowledges a grant as Bevoegdverklaard Navorser of the Nationaal Fonds voor Wetenschappelijk Onderzoek, Belgium. This research was made possible by the Geconcerteerde Aktie voor het Wetenschappelijk Onderzoek, Ministerie van Wetenschapsbeleid, Belgie. Robert Schoonheydt thanks prof. J. B. Uytterhoeven for his stimulating interest in this work.

\section{DISCUSSION}

\section{Question. - K. FunKe.}

Which were your experimental relaxation times obtained from your Cole-Cole plots?
Reply. - R. A. SchOONHEYDT.

The relaxation times were in the $\mathrm{MHz}$ range.

\section{References}

[1] BRECK, D. W., Zeolite Molecular Sieves. Structure, Chemistry and Use (Wiley Interscience New York) 1974.

[2] Sмith, J. V., Adv. Chem. Ser. 101 (1971) 171.
[3] Jansen, F. J. and Schoonheydt, R. A., J. Chem. Soc. Faraday Trans. 169 (1973) 1338.

[4] SCroonheydr, R. A. and DE WILde, W., J. Chem. Soc. Faraday Trans. 170 (1974) 2132. 
[5] Schoonheydt, R. A. and Velghe, F., J. Chem. Soc. Faraday Trans. 172 (1976) 172.

[6] Mortier, W. J., Bosmans, H. J. and Uytterhoeven, J. B., J. Phys. Chem. 76 (1972) 650.

[7] Macedo, P. B., Moynihan, C. T. and Bose, R., Phys. Chem. Glasses 13 (1972) 171.

[8] Howell, F. S., Bose, R. A., Macedo, P. B. and Moynihan, C. T., J. Phys. Chem. 78 (1974) 639.

[9] Trurrzo, I., Mariani, E. and Barancok, D., Czech. J. Phys. B 24 (1974) 203.

[10] Costenoble, M. L., Mortier, W. J. and Uytterhoeven, J. B., J. Chem. Soc. Faraday Trans. 174 (1978) 466.

[11] Gallezot, P., Ben TaArit, Y. and Imelik, B., J. Catal. 26 (1972) 295.
[12] Hill, N. E., Vaughan, W. E., Price, A. H. and Davies, M., Dielectric Properties and Molecular Behavior (Van Nostrand New York) 1969, ch. 1.

[13] Sato, H. and Kikuchi, R., J. Chem. Phys. 55 (1971) 677.

[14] KikuChI, R. and Sato, H., J. Chem. Phys. 55 (1971) 702.

[15] KIKUCHI, R., Fast Ion Transport in Solids. Solid State Batteries and Devices (Ed. W. Van Gool, North Holland Amsterdam) 1973, p. 249.

[16] MORTIER, W. J., J. Phys. Chem. 79 (1975) 1447.

[17] Manning, R. J., Diffusion Kinetics for Atoms in Crystals (D. Van Nostrand, Princeton New Jersey, USA) 1968, ch. 3 . 